\title{
Revising the Settler Colonial Story in Albert Wendt's Black Rainbow
}

Kara Hisatake

\section{OpenEdition}

1 Journals

Electronic version

URL: https://journals.openedition.org/ces/394

DOI: $10.4000 /$ ces.394

ISSN: 2534-6695

Publisher

SEPC (Société d'études des pays du Commonwealth)

\section{Printed version}

Date of publication: 30 November 2018

Number of pages: 83-93

ISSN: 2270-0633

\section{Electronic reference}

Kara Hisatake, "Revising the Settler Colonial Story in Albert Wendt's Black Rainbow", Commonwealth Essays and Studies [Online], 41.1 | 2018, Online since 05 November 2019, connection on 23 August 2021. URL: http://journals.openedition.org/ces/394 ; DOI: https://doi.org/10.4000/ces.394

\section{(c) $($ †) $\ominus$}

Commonwealth Essays and Studies is licensed under a Licence Creative Commons Attribution - Pas d'Utilisation Commerciale - Pas de Modification 4.0 International. 


\section{Revising the Settler Colonial Story in Albert Wendt's Black Rainbow}

Albert Wendt's Black Rainbow (1992) has been read as an example of a postcolonial and postmodern novel by most literary scholars, as it is a narrative influenced by deconstructionist thinkers and located in New Zealand's colonial history. However, I argue that the novel must also be understood as settler colonial critique, which interrupts the settler story of conquest, settlement, and Indigenous erasure. Intervening in the stories of successful white settlement that deny a national history of colonial violence, Black Rainbow shatters the teleological presumption of a settler future. Wendt's novel offers a decolonizing method of reading, which emphasizes re-readings, revisions, and choice, as well as Māori, Pacific Islander, and Pākehā solidarity.

Albert Wendt's Black Rainbow (1992) imagines a dystopian Aotearoa New Zealand with a totalitarian government called the Tribunal. The Tribunal, Elizabeth DeLoughrey highlights, is a reflection of the Waitangi Tribunal hearings process, which investigates Crown inconsistencies in honoring the 1840 Treaty of Waitangi with its Māori Treaty partners, especially over land claims (204). ${ }^{1}$ The Tribunal in the novel attempts to erase New Zealand's history of colonial violence and the presence of Māori people, espousing a sanitized national narrative that does not recognize indigeneity. However, the middle-aged protagonist, unnamed for most of the novel, reveals a method for countering this dystopian version of history. In a journey that takes him through the New Zealand landscape and literature, he offers a re-reading that foregrounds Māori and Pacific Islander presence on the land and within literature and history. The novel, I argue, disrupts the story of settler colonialism to show that reading is one method of decolonization. Reading against the grain, often in resistant and rebellious ways, unsettles the grip of the settler colonial present and the past the Tribunal attempts so hard to deny. As part of this unsettling, Wendt also demonstrates that there is no "pure" indigeneity or Indigenous forms, but as both protagonist and reader engage in reading and revising, we come to understand that indigeneity is open to mixture and adaptation. In doing so, Black Rainbow remembers the multiple literatures and histories that make up New Zealand to envision a decolonized Aotearoa.

Declaring that "[h]istory is a curse" from which "[they] must be free" (21), the Tribunal calls upon the protagonist to confess his personal history. Through "Dehistorying," a process in which the government is described to "assum[e] total responsibility for his history and the crimes and sins of the past," the protagonist becomes an "ideal citizen" (33). He is given a piece of paper known as a "Reference," and in it the Tribunal declares that "[n]othing is to be denied to him," for "he is now of [the State], forever" (33). Yet the Tribunal cannot escape the past that they try to erase in the Dehistorying process.

1. The Treaty of Waitangi (1840) was a contract between British settlers and many Māori tribes that established British annexation, but which often rendered void Māori rights. The Tribunal was established in 1975 to process land alienation claims as the government began to privatize national resources. Māori claims brought to the Tribunal often utilized whakapapa, a performative genealogy that is an Indigenous epistemology, to counter settler land claims (see DeLoughrey 164-6). 
The protagonist becomes a full citizen through being, in the Tribunal's words, "free of our past, our guilt" (33). This can be understood by the way in which Wendt points to the violence of New Zealand's settler colonialism, a violence that haunts the national past. In the novel's vision of the Tribunal, Māori are notably absent from the land and Tribunal arbiters declare that citizens are absolved of a shameful national past and must live in "the present, the eternal instant" (28). For all those affected by settler violence, this vision dangerously suggests that forgetting the past solves the problems of the past.

Black Rainbow, at its core, is about storytelling. Much scholarly attention focuses on the novel as postmodern or on how it takes postmodernism into a postcolonial context. A story about other stories, the novel's intertextuality ends up emphasizing how stories are constructed. Storytelling and its techniques have been Wendt's preoccupation and in Black Rainbow he specifically notes that his focus is the construction of history in New Zealand by colonizers (Ellis, "The Techniques" 79-80). The Tribunal's Dehistorying process deploys a narration of the nation to erase past violence, and the Tribunal's total narrative control means that the protagonist is limited in his attempts at subversive or revisionist storytelling. The supposedly ordinary and harmless bank clerk, sent on a government-sanctioned Quest to search for and reunite with his wife and children, is directed in a Tribunal story, contained, controlled, and televised as a national heroic journey. Stressing the performance of power, Wendt's capitalization of Tribunal, Quest, Dehistorying, and Reference indicate the extent of the Tribunal's narrative control. ${ }^{2}$ Wendt brings to life a version of the nation that refuses to wrestle with an essential aspect of the history of its founding: settler colonialism and its contemporary ongoing effects. The narrative of the settler colonial nation denies not only Indigenous history but also the violence of settlement through Indigenous containment and elimination. The novel, as I will show, stresses the importance of reading, interpretation, and the revision process for decolonizing (his)stories.

\section{Disrupting the Settler Story}

Black Rainbow is often designated as postcolonial for its attention to the colonization of Aotearoa New Zealand, and postmodern for its self-reflexivity, intertextuality, and pastiche. Although the postcolonial and postmodern lenses are useful in understanding the novel, settler colonial critique may be more apt. ${ }^{3}$ Wendt himself debunks postmodernism, claiming that many of its concepts can be traced to Indigenous Pacific oral and philosophical traditions and that, as Juniper Ellis points out, "Polynesian practices anticipate postmodernism" ("A Postmodernism" 104). Techniques he deploys in the novel, such as calling attention to the constructive nature of narrative, reflect fagogo, Samoan storytelling with a set form that includes a flexibility allowing the storyteller to weave in tangents and subplots (Ellis, "The Techniques" 83). A break from the social realism associated with white settler nationalism, Black Rainbow demonstrates a commitment to

2. I retain Wendt's capitalization throughout.

3. For more on Black. Rainbow as postmodern or resonating with poststructuralist theories, see Juniper Ellis's "A Postmodernism of Resistance" (1994), Paul Sharrad's Albert Wendt and Pacific Literature (2003), Elizabeth DeLoughrey's Routes and Roots (2007). Most critics do not dispute Wendt's use of postmodernism and often add that he brings a postcolonial perspective; DeLoughrey differs in that she claims that he "ultimately affirms a localized and corporeal definition of place in the wake of globalized, postmodern, and corporate hegemonies" (201). 
settler colonial critique and the endurance of Indigenous epistemologies of genealogical continuity. ${ }^{4}$

Wendt enables a counter-reading of nation, literature, and Indigenous identity through the protagonist's globalized and urbanized Indigenous identity. As critics like Elizabeth DeLoughrey and Paul Sharrad have noted, mixed heritage can undermine Indigenous claims to land from the perspective of postmodernism and social constructivism. ${ }^{5}$ Heritage, through the lens of settler colonial blood quantum policies, becomes one way of determining what counts as authentically Indigenous, and therefore restricts land claims. The novel's protagonist might be mixed, but Wendt suggests that this identity, rather than undermining Indigenous claims, must also be understood as a reframing of contemporary Indigenous Pacific identity. To think otherwise would mean falling into the settler logic of blood quantum, in which the only "true" Indigenous are those with undiluted, pure blood; anyone else becomes assimilated into white culture. Such settler notions do not account for the capaciousness of Indigenous genealogies.

Settler colonialism, after all, is premised on displacing or replacing Indigenous peoples from the land and making settlers "native"; Patrick Wolfe famously emphasized that this definition is the logic of Indigenous elimination, according to which "colonizers come to stay - invasion is a structure not an event." (2) This points to how settler colonialism is ongoing, as settlers continue to dispossess and maintain Indigenous territory. There is no voyage home for settlers. The logic of elimination and exclusion frames the structure of settler colonialism and its everyday effects. Reading Patrick Wolfe, Iyko Day writes that the logic of exclusion includes practices of segregation, police brutality, and detention - maintaining control over an Indigenous population through exclusionary measures. The logic of elimination is genocide, whether through killing or assimilation. As Day argues, "[e]xclusion and elimination are not discrete logics but operate on a moving spectrum of biological violence" (25). Storytelling is central to settler colonial logic of elimination, and according to Lorenzo Veracini, the story the settler tells helps to bury the history of violence. The story of settler colonialism is a teleological linear narrative of "travel penetration into the interior, settlement, endurance, and success" (98). An "irreversible transformation" from travel to settler success (98), the settler colonial story conveys the settler's aim to live in the triumphant present that denies Indigenous peoples' struggles for sovereignty, since recognizing their struggles would be equivalent to going back to a time before settler success. The settler narrative is a pervasive form of science fiction, in which "the future [i]s an extension of a settler colonial past" (102). ${ }^{6}$ Black Rainbow, however, resists this science fiction trope.

4. See Ellis's “A Postmodernism of Resistance" on examining Wendt's “social realist” works in the light of the postmodernism of Black Rainbow. DeLoughrey also notes that " $[\mathrm{t}]$ he realist novel in Aotearoa / New Zealand has a particular relationship to white-settler nation-building. As the first Samoan writer to rescript native literary and national identity in Aotearoa / New Zealand, Wendt cannot afford to uphold the realist novel if he is simultaneously to situate native agency outside the boundaries of the homogenizing nation-state" (225). See Michelle Keown's Pacific Islands Writing (2007) for more on settler literary nationalism.

5. DeLoughrey writes that "in some parts of Oceania, claiming multicultural antecedents may undermine Indigenous claims to ancestral land. Since most settler nation-states require some type of blood quantum to authenticate identity, destabilizing native ancestry has significant material consequences" (198); Sharrad points to the postmodern dilemma of constructs - "if everything is a construct of textual surfaces, then identity politics and minority claims to authority are undermined" (206).

6. See John Rieder's Colonialism and the Emergence of Science Fiction (2008) for more on colonialism as foundational to science fiction. 
The novel questions the legitimacy of settler colonialism for New Zealand's present, challenging settlers' temporality. While on the surface Black Rainbow projects itself into a science fictional future that is an extension of the settler colonial past, the novel does not allow this past to determine its plot. The Tribunal's restrictions on history mean that there is no direct settler colonial story of conquest told; however, there are many indirect signs of this story. Seeing Polynesian street kids, the protagonist's companion is frightened, saying that they "refus[e] to be like us, be law-abiding citizens" (Wendt, Black Rainbow 27). In her perspective, because "[n]o one can reform them" they are put into "reordinarination centres but come right back to the streets. Must be in their blood" (27). Reordinarination suggests reeducation as well as making citizens "ordinary" - a gloss for inhabiting a white settler worldview with appropriately white ways of behaving. Later in the novel when the protagonist attacks hunters who try to kill him during his Quest, they cry out "you're still a savage" (98, emphasis mine). In another scene, the members of the Tribunal insist that the "savages who once lived" at Maungakiekie (the Māori name for One Tree Hill, as Wendt reminds readers) "were meateaters too" who "were eaten by other meateaters" (16). These many allusions to savage behavior mean that history is still present; this settler story places indigeneity temporally behind - Māori and other Pacific Islanders are seen as uncivilized, while white settlers progress into modernity. As Wendt makes clear, reordinarination helps white settlers believe they have brought Polynesians into modernity, yet it is the white settlers who cannot forget the latent tropes of savagery and cannibalism. The Dehistorying of the nation only temporarily keeps settler anxieties at bay before the settler story, which traps the Indigenous in an earlier time and is rife with stereotypes, returns to the fore.

The protagonist is told a more complete version of national history during the Quest for his family, when he meets three young urban Tangata Māori or Indigenous Māori on the streets and they reveal to him that they are the Tangata Moni, the "True Ones": "Over the long stretch of otherworlder oppression and arrogance, the Tangata Māori, our pre-otherworlder ancestors, were nearly all erased, physically and culturally [...] further erased through intermarriage and reordinarination [they] merged with our sisters and brothers from the Islands who were being reordinarinised, and became the Tangata Moni, the True People" (157-8). ${ }^{7}$ Tangata Moni also include "Pakeha / palagi, who saw the injustice in reordinarination" (158). The name Tangata Moni, therefore, designates the descendants of Māori, Pacific Islanders, and Pākehā who survived the onslaught from the otherworlders, their word for settlers. The name "otherworlders" points to foreign invasion and settlement, while the "True Ones" remind readers that solidarity with Māori self-determination is possible. The young men tell the protagonist that multinational corporations, Tribunals, and reordinarination all represented methods of elimination directed at anyone "who challenged the system" (158). In this history of resistance, Wendt refuses to create binaries of Māori or Pākehā (or native / settler), and this political unification against the Tribunal results in the mixing of their Tangata Moni descendants. Their mixed ancestry highlights "the contingency of indigeneity as well as its regional and global histories" (DeLoughrey 217). Although critics

7. DeLoughrey notes that "moni" means "truth" in Samoan and a transliteration of "money" in Māori, leading her to conclude that "Wendt seems to be invoking not only the ways in which native subjects are falsely interpellated by the subjugations of transnational capital, but he is also gesturing to how the treaty claims process has instituted a legal exchange of history for capital" (221). 
like DeLoughrey, Ellis, Sharrad, and Michelle Keown understand this mixed heritage as a form of survival for the urbanized, globalized indigenous peoples subject to colonial assimilation, they consider it a condition of postcolonialism rather than one of settler colonialism. Understanding the mixed heritage of the Tangata Moni points to a form of Indigenous survival under settler colonialism and recognizes the logic of elimination. In Black Rainbow, displacing and replacing Indigenous peoples takes the form of outright elimination - genocide - alongside assimilation. Contrary to the blank national history told by the Tribunal, New Zealand history unfolds from the narrative told by the three youths who describe it from the Tangata Moni perspective rather than from that of the successful settler. It is not a story of reform and cleansing but one of resistance and survival. As such, this revision of the settler story is a form of political activism, which Wendt sees as a writerly political commitment to an "exploration of colonialism and its effects" (Ellis, “The Techniques" 85), or as Julia Boyd says of Wendt's novel, an "intervention into SF [a]s a significant form of literary activism" (675).

Divulging their full history, the Tangata Māori youth - Manu, Fantail, and Aeto help the protagonist on his path to rebelling against the Tribunal. ${ }^{8}$ With them, he finds a different kind of family than the reordinarinized family for whom he was originally searching, and comes to reject the fatherly President and the Tribunal-as-family-whoknows-best that the government desires for their subjects. He finds 'aiga, the Samoan word meaning family, which encompasses extended kinship ties, unlike the Western notion of a nuclear family. The youths are quick to call him out as a white-washed Pacific Islander, telling him "[the Tribunal] fucked you up good" because he is "brown on the outside and filled [...] full of white, otherworlder bullshit" (123). Part of the protagonist's journey involves recognizing and accepting himself as brown. Despite being absolved of his own history, from the beginning the protagonist is marked as Polynesian, a mark the Tribunal cannot erase. He compares Polynesian street kids to his own children, and experiences discrimination - something the Tribunal has failed to reordinaranize away. During his Quest, he waits to speak to the receptionist at a hotel but when he sees her face he thinks "my past was here again" (49). Since she refuses to look at him and ignores him outright, he becomes angry and complains to the manager about this rudeness, thinking "[i] t was all back: my life, my family - our history of being discriminated against, a history the self-sacrificing Tribunal had assumed the guilt and responsibility for but which the hunters, the receptionist [...] had brought back" (50-1). Although the Tribunal's national anthem suggests a state of utopia that outlaws war, hunger, poverty, disease, crime, and even "intolerance" (73), touting equality for all, it cannot dispose of either the guilt or the consequences of settler colonialism, including the logics of elimination and exclusion, which undermines Indigenous presence and espouses racialized prejudice and hate. Nor can this utopia seem to rid itself of the "deviant" existence of the Tangata Moni. Tangata Moni history cannot be contained by the settler story.

At first that history is one of pain, discrimination, and willful ignorance on the part of the protagonist. At the beginning of the novel, his wife speaks about the original people of Maungakiekie, noting that "[t] he Pakeha have changed the vegetation but they're still here" and the protagonist responds by pretending he "didn't know who she

8. Fantail's real name is Piwakawaka, "Maui's cheeky bird" (Wendt, Black Rainbow 142), a bird which comes from the tales of Maui's adventures and tends to be a bit of a trickster itself. 
was referring to" (12). But after his meeting with the Tangata Moni, who alert the protagonist to the Tribunal's tricks, this history becomes meaningful no matter how fragmented. The Tangata Moni narration of their origins, moreover, refuses the assimilative logic of blood quantum - they proudly recite the genealogy they know. For her and Manu, Fantail says, "Dad was part-Samoan, part-Maori, part-Pakeha" and "Mum was mainly Maori, with a dash of Scotch, a little bit of Tongan, and a lemonslice of Pakeha" (143). Even though they were never able to meet their parents because, she explains, Dad "disappeared into the Tribunal's reordinarination centers" and "Mum took up with other guys, who abused and used her, and she was dead of an overdose before I was one" (143), they can recall from whom they are descended. Aeto, who was born in the Tangata Moni sanctuary Wanganui-a-Tara but has survived countless reordinarinations, knows his family as well - he says his father "Kuki Patrick Malama, was Tangata MaoriNiuean-Samoan-Pakeha-Irish, and his mother, Merimeri, Maori-Tokelauan-Cook Islander-German" (158). They recite these genealogies and what they know of their own history and where they come from despite the Tribunal's prohibition on history. Cultural tradition may be fragmented, but "occasionally they invoke familial practices of tangi (mourning), oral storytelling, and the remnants of their native languages" (DeLoughrey 217), such as the language the protagonist overhears - "English bits and a few Polynesian pieces, the rest was street pidgin, their coinage" (Wendt, Black Rainbow 123).

Such whakapapa, or genealogy, forms the basis of their urban Polynesian identities and includes stories of where they come from, who raised them, and their cultural contexts. Fantail and Manu talk about their Aunt Hena who raised them "slog[ing] her guts out in a factory during the day and a cleaning job at night" (143), like "most Tangata Maori mothers" (143). In Aeto's whanau, otherworlders had sterilized the women (158). These common stories of the Tangata Moni lead Fantail to conclude that reordinarination "domesticate[s]" them from so-called savagery (144). In these stories, Wendt forms a version of the Indigenous urban subject, who is specifically transpacific, and roots resistance, as DeLoughrey claims, in a "globalized series of material and cultural relations" because he "suggests Indigenous peoples must incorporate other epistemologies into local whakapapa to articulate the layering of a multiethnic subjectivity" (222). Since Māori whakapapa trace ancestry to Papatūānuku, the founding mother deity, they function as counter-narratives to "colonial accounts of linearity and progress" by "encoding European colonialism as both unnatural and ahistorical" and foregrounding historical, communal, and familial memory (166). As much as possible, the Tangata Moni present whakapapa that locates their resistance to settler culture and connects their roots to Aotearoa, no matter how mixed their blood. Their culture exists, contrary to the accusations of the jury member Cantos, who contends that "Tangata Maori culture no longer exists, or, if it does, it does so only in bastardised criminal form" (Wendt, Black Rainbow 254). 'Drawing on DeLoughrey's analysis of Black Rainbow's "global indigeneity based on a politics of resistance" (222), I read the Tangata Moni as a form of endurance under settler colonial structures, for they provide a legitimation of mixed-race indigeneity regardless of blood percentage and displays Wendt's contention that authentic

9. Cantos is a reference to Karl Stead, a former professor at the University of Auckland. Stead held opinions similar to those of Cantos, something for which Wendt criticizes Stead in his essay "Pacific Maps and Fiction(s)." The figure Cantos embodies attitudes that ignore Māori culture or indigeneity and further white settler nationalism. 
indigeneity means one that is alive in the present. ${ }^{10}$ From his early essay, "Towards a New Oceania," Wendt emphasizes that "usage determines authenticity" (52), for in his view "[o]ur quest should not be for a revival of our past cultures but for the creation of new cultures which are free of the taint of colonialism and based firmly on our own pasts" (53). In Black Rainbow, Wendt is able to reawaken the protagonist to the larger contexts and meaning of history; he is able to see history as something which connects him to a family, culture, and place that the Tribunal is attempting to destroy: the novel pits such Indigenous survival against the settler story.

Finally recognizing himself as brown, the protagonist embraces the history he can remember, and finds records of his past. Needing to reconcile himself to the fact that his family is reordinarinized by the Tribunal, he thinks, "[t]hough the Tribunal has banned history, we are what we remember, the precious rope stretching across the abyss of all that we have forgotten" (178). Through learning his own past, the protagonist discovers he has had three different lives: the first as Patimaori Jones, the illiterate young Tangata Māori; the second as Supremo Jones, a superb hunter for the Tribunal whom the President considers a son; and the third as Eric Mailei Foster, the ordinary bank clerk. Made aware of his own identity and its construction, he further builds it through a whakapapa reading of the work of Tangata Moni writers that gives him a world, identity, and genealogy he could not find in his own fragmented history, a history which had been structured by the settler story. Wendt even quotes from Donna Awatere's Maori Sovereignty in his novel:

Who I am and my relationship to everyone depends on my whakapapa, on my lineage, on those from whom I am descended. One needs one's ancestors therefore to define one's present. Relationships with one's tipuna are thus intimate and causal. It is easy to feel the humiliation, anger and sense of loss which our tipuna felt. And to take up the kaupapa they had. (qtd. in Wendt, Black Rainbow 244)

A call to action, Awatere's words affirm the protagonist's connection to the land and ancestors beyond his immediate family and relate him to Pacific stories and histories.

Far from a settler story, Black Rainbow is a narrative of whakapapa reconnection, or learning about and from one's history, including a national past that acknowledges Māori history alongside the colonial violence of the settler nation-state. The novel disrupts a smooth settler colonial story of Aotearoa New Zealand as a land of tamed Māori and Pacific Islanders, or a land from which they are entirely absent. In a science fiction thriller that critiques the settler story or the narration of national (and personal) history, Wendt imagines a future in which the settler colonial past can never be forgotten and becomes part of the story of Indigenous resistance, and the story located in whakapapa takes center stage. Moreover, this story embraces an Indigenous sense of belonging, not that of blood quantum, which Wendt calls "an old racist trick" that "claim[s] that because we're part-Pakeha we're all Pakeha and no longer Maori or Samoan" ("Pacific Maps" 19). Indigeneity and identity are presented as mixed, a "politically invested practice" (Sharrad 217). Black Rainbow's whakapapa practices show Wendt's notion of an authenticity that is grounded in its present usability and not stuck in the past. His "usage

10. DeLoughrey makes an important point about blood quantum and the separation of urban and iwi Māori in the 1992 Treaty of Waitangi (Fisheries Claim) Settlement Act. This act designated all Māori as treaty partners, but a series of rulings made it so that only Māori affiliated with iwi received financial compensation, leaving a number of Auckland Māori who could not establish tribal affiliations without compensation (221). 
determines authenticity" becomes useful for recognizing mixed identities and histories as Indigenous when they might be seen as assimilated or "impure" in settler logics.

\section{Decolonizing Reading, Enacting Agency}

The acts of reading and interpretation are key to the protagonist's resistance to the Tribunal and his awakening to his own history and genealogy. The protagonist has already started reading to search for a sense of connection to his whakapapa. In "Towards a New Oceania," Wendt argues, "[t]here are no true interpreters or sacred guardians of any culture. We are all entitled to our truths, insights, and intuitions into and interpretations of our cultures" (54). In this novel, too, Wendt stresses the importance of the act of interpretation through re-telling or re-reading. The protagonist's active reading allows him to awaken to the truth of his own culture and the repressive nature of the Tribunal. This reading, which invokes Indigenous agency, goes against the inevitable settler story.

At first, reading constitutes a way for the President to "tame" Patimaori. As the protagonist learns, Patimaori is illiterate and so the President teaches him how to read and write because from the President's perspective, the "magic of the printed word will tame him, convert him to civilisation, make him thirst for our cargo, like primitives in the past" (226). He loves reading so much that when Patimaori becomes Eric Mailei Foster, the President programs "a wide and deep knowledge of modern fiction and poetry, especially that of [New Zealand]" into his personality (228). Reading in itself gives the protagonist Pākehā knowledge. But interpretation is what galvanizes the protagonist into resistance, particularly through the mysteries of the Puzzle Palace, the place he must infiltrate to find his family. The Puzzle Palace is the popular name for the "Government Insurance Corporation" (136), what Fantail calls "just another fucking ugly office building" holding the civil servants of settler colonialism (136). ${ }^{11}$ Combing over the Puzzle Palace but unable to find any of its secrets, the protagonist wonders: "Could it be that we're reading it wrongly?" (138). The Palace, he senses, is "scrutinising me, challenging me, saying: 'I can read you but you can't read me"' (142), as if reading is the necessary tool for success in his endeavor. Armed with research from the City Library and knowing he must re-read the building, the protagonist lays out multiple readings of the Puzzle Palace: Government Insurance Corporation, a surveillance centre and a secret training facility for elite hunters. To carry out their operation, they must "[a]gree on one reading of Palace as surveillance centre and prison" (149), and only then are they able to break in and find the protagonist's family. Their success is attributed to multiple readings beyond a first glance, and the active decision to see the Palace as more than an office building.

Auckland, the country's landscape, and literature itself are subject to re-interpretation in the novel, beginning with the Ralph Hotere Black Rainbow / Moruroa lithograph, from which Wendt takes the novel's title. The lithograph is from a series of works that Hotere produced as a way of protesting the French testing of nuclear bombs in the Pacific. The protagonist's wife uses the lithograph, as he describes, "to bless the earth and protect it from the clock of doom that ticks in our pulses" (31). Although he likes the print, the protagonist cannot understand his wife's actions nor the lithograph's

11. It also refers to the James Bamford book The Puzzle Palace (1982) on the history and workings of the National Security Agency, a US intelligence organization. 
meanings - he questions why it is a black rainbow and what the countdown means - yet as his journey goes on he sees the lithograph as a lifeline to his whakapapa. As one of his last acts of rebellion, the protagonist goes to One Tree Hill, a place he re-reads and re-names with its Māori name, Maungakiekie, to await the sun and "turn [his] flesh and history into sinews of light that bound with everything with its unbreakable genealogy" (242). He buries the lithograph there, but not before "read[ing] the Hotere clock once more" (243). As Wendt notes in an interview, "there is always a double meaning: in Maori and Polynesian cultures, pouliuli or the colour black is a fertile colour, a fecund darkness. So by calling it 'Black Rainbow' there is still an element of hope" (Ellis, "The Techniques" 87). This fertile darkness explains why Wendt quotes Hone Tuwhare's poem "We, Who Live in Darkness" in his novel, for with darkness comes light (196-7). In the scene on Maungakiekie, the protagonist is renewed by the sun and life around him, including the remembrance of the Māori dead buried at Maungakiekie, and is satisfied that although the Hotere clock might be ticking towards doomsday, it still "ticked vigorously" (243). Reading the Hotere clock is a reminder of the destruction of the past and of survival, while serving at the same time as a point of connection to his blood and the earth, his wife, Hotere and Tuwhare's resistance, and the fertile possibilities to come out of dystopia.

What gives the lithograph and the Puzzle Palace their importance is the way the protagonist reads them. Active reading gives the protagonist agency to revise the Tribunal's total Dehistorying of Aotearoa in landscape and literature. Learning to read the Puzzle Palace, the protagonist re-learns Auckland from the perspective of the Tangata Moni street kids:

Using the maps, they took me block by block, street by street, through the inner city. Names of businesses, buildings, places, gossip about those, recent happenings, some history, stories of crimes and daring deeds they'd committed against those people and places. They even filled in what wasn't in the maps, especially when we descended into the labyrinth below the inner city, into a world I knew nothing about. [...] 'A city is layers of maps and geographies, layers of them, centuries of it. We were the first, our ancestors, no matter what lies the Tribunal says. So our maps are at the bottom of the bloody heap. They're still there though the otherworlders have tried to fucking well erase them. As long as we survive...' Manu said. (134)

Reading maps is a political and rebellious act. Learning these other ways of reading, of seeing the inner city, is a method of decolonization and resists the concretized settler story. Wendt describes his own work as "restor[ing] to the landscape of Auckland the original Maori maps" (Ellis, "The Techniques" 85), and explains that his novels try to "decolonize" what has been erased and written over (86). Furthermore, through the stories of the Tangata Moni youth, the Tribunal is "a palimpsest over native presence" (DeLoughrey 217), which comes to form the very foundations of the state itself. Learning from the Tangata Moni, the protagonist is able to re-read the Puzzle Palace and his own tangled history, an act which then creates opportunities for him to rebel against the Tribunal's pre-determined plans for him.

Wendt includes fiction and literature in his definition of maps. In the essay "Pacific Maps and Other Fiction(s)," he writes that "[n]ovels are about other novels" (28), a line oft repeated in Black Rainbow as "a story is about other stories" (72). In his essay he refers to "stereotyped maps and fictions" that EuroAmerican novels such as Robinson Crusoe create about the Pacific, and his own frustration at seeing islands "through those 
clichéd maps" (28). Echoing this sentiment, the novel's protagonist muses, "we see reality through art and the other cultural baggage we carry" (65). In the essay, Wendt's solution to these stereotyped maps is to write in order to break free. But as the novel demonstrates, the act of reading is just as important. The Tangata Moni kids' makeshift whare includes a revision of canonical texts: "Hone Tuwhare's Mibi; Donna Awatere's Maori Sovereignty; Ranginui Walker's Nga Tau Tohetohe and Ka Whawhai Tonu Matou: Struggle Without End; Bill Pearson's Fretful Sleepers; Jim Baxter's Collected Poems; Patricia Grace's Potiki; Dick Scott's Ask That Mountain; Witi Ihimaera's The Matriarch; Albert Wendt's Ola" (157). A gathering of foundational Pacific literature, the whare's literature provides a counterpoint to white settler New Zealand writing or the references to canonical world literary texts scattered throughout the novel. In many ways a new nationalist literature, this collection is capacious, for not only does it list writing by prominent Māori and Pacific Islanders, it also includes Bill Pearson, James Baxter, and Dick Scott, white settlers who significantly contributed to Māori and Pacific Islander history and representation. ${ }^{12}$ This decolonizing national literature embodies the Tangata Moni themselves - a mixture of resistant Māori, Pacific Islanders, and Pākehā who ground themselves in the often forgotten history of Aotearoa New Zealand.

Active reading and interpretation thus make resistance possible. While the protagonist's family has been reprogrammed and he is unable to truly "rescue" them, he re-interprets his own history to figure out what he should do next. He understands the construction of stories and identities, finally seeing "connections I'd not been aware of before, between my characters, until the walls were crisscrossed, bridged, connected with arrows, talk balloons, crossings-out and insertions, analogies, metaphors, similes, speculations, curses of frustration" (189). Embodying the writerly and readerly process of revision, the protagonist comes to peace with his history, for he concludes that "[his family's] love for one another had not been a fabrication, a pre-programmed feature. [His] memories of them were real, a history that helped give [him] meaning. A history [he] now wanted to stop the Tribunal from taking away from [him]" (192). Although he no longer has his family, the protagonist refuses to lose his memories of them, for to lose his history is to forget who he is. Analogous to the loss of family and aiga created by settler colonialism, the protagonist's new goal is to find justice where it is possible within a system built against him and remember his own history without being erased.

In the end, how the protagonist lives or dies is a choice given to the reader. The protagonist suggests " $[\mathrm{w}] \mathrm{e}$ are, in the final instance, allegories that are read the way the reader chooses" (265), and the very last sentence reads: "Readers are free to improvise whatever other endings / beginnings they prefer" (267). As Sharrad notes, "[c]hoice (and thus politics) is always implicit in interpretation" (220), which puts true agency for the future - of Aotearoa, Māori sovereignty, history, literature, and all that Wendt includes in Black Rainbow - in the hands of the reader. In a novel that leads the protagonist through a decolonizing process, one of the most important choices here is whether the reader will take responsibility for a painful history structured by settler colonialism, or deny responsibility altogether. For those who make that choice, reading can become a mode of decolonization, thus actively unsettling settler colonialism.

12. Bill Pearson mentored future Māori leaders at the University of Auckland and wrote about the depiction of Māori in New Zealand literature. James Baxter worked as an activist to preserve Māori culture. Dick Scott recounted the history of Māori resistance to European occupation. 
Although the novel was written in the 1990s, it is still significant to the present and is especially relevant to how the New Zealand landscape has come to be viewed in the state-led tourism post-Lord of the Rings as "a global fantasy of whiteness" with imagery that revisits the colonial era (Werry 207). In contrast to the alternate world in Lord of the Rings, Black Rainbow's alternative reality leads away from white settler fantasy and into questions of history, identity, and memory firmly tied to the present. Black Rainbow anticipates a critique of the settler story of the nation. Wendt attempts to gesture toward Māori sovereignty as a migrant himself - perhaps as someone Jodi Byrd might term an "arrivant," a word from Kamau Brathwaite that "signif[ies] those people forced into the Americas through the violence of European and Anglo-American colonialism and imperialism around the globe" (xix). As a Samoan in Aotearoa, Wendt argues that "though I'm a new migrant here, and my ancestors were not responsible for the injustices committed against the Tangata Maori, I am benefitting like everyone else (including fifth-generation migrants), from the fruits of those injustices and a system which has institutionalised racism against the Tangata Maori" ("Pacific Maps" 40). He outlines the problem of many settlers and migrants who realize that they are on unceded Indigenous territory. His solution is to help support the work for Māori sovereignty even as a migrant Pacific Islander ("Pacific Maps" 40). In Black Rainbow, he approaches the sovereignty struggle through the Tangata Moni, a people who embody a politics of resistance from across the native / settler / migrant divide. Wendt articulates a process of decolonization that is located in the act of reading and interpretation.

\author{
Kara Hisatake \\ University of California, Santa Cruz
}

\title{
Works Cited
}

Boyd, Julia. "Black Rainbow, Blood-Earth: Speaking the Nuclearized Pacific in Albert Wendt's Black Rainbow." Journal of Postcolonial Writing 52.6 (2016): 672-86.

Byrd, Jodi. The Transit of Empire: Indigenous Critiques of Colonialism. Minneapolis: U of Minnesota P, 2011.

DAY, Iyko. Alien Capital: Asian Racialization and the Logic of Settler Colonial Capitalism. Durham: Duke UP, 2016.

DeLoughrey, Elizabeth. Routes and Roots: Navigating Caribbean and Pacific Island Literatures. Honolulu: U of Hawaici P, 2007.

ElLis, Juniper. “A Postmodernism of Resistance: Albert Wendt's 'Black Rainbow'.” Ariel 25.4 (1994): 101-14.

—. “The Techniques of Storytelling': An Interview with Albert Wendt.” Ariel 28.3 (1997): 79-94.

Keown, Michelle. Postcolonial Pacific Writing. New York: Routledge, 2005.

Sharrad, Paul. Albert Wendt and Pacific Literature: Circling the Void. Manchester: Manchester UP, 2003.

VeracinI, Lorenzo. Settler Colonialism: A Theoretical Overview. Houndmills: Palgrave Macmillan, 2010.

Wendt, Albert. Black Rainbow. Honolulu: U of Hawai'i P, 1995.

—. "Pacific Maps and Fiction(s): A Personal Journey." Meridian, "Asian and Pacific Inscriptions: Identities, Ethnicities, Nationalities" 14.2 (1995): 13-44.

—. "Towards a New Oceania." Mana 1.1 (1976): 49-60.

Werry, Margaret. The Tourist State: Performing Leisure, Liberalism, and Race in New Zealand. Minneapolis: U of Minnesota P, 2011.

Wolfe, Patrick. Settler Colonialism and the Transformation of Anthropology: The Politics and Poetics of an Ethnographic Event. London: Cassell, 1999. 